\title{
From Silence to Golden: The Slow Integration of Instruments into Christian Worship
}

Jonathan M. Lyons

Cedarville University, jlyons@cedarville.edu

Follow this and additional works at: https://digitalcommons.cedarville.edu/musicalofferings

Part of the Christianity Commons, Fine Arts Commons, Liturgy and Worship Commons, Musicology Commons, and the Music Performance Commons

DigitalCommons@Cedarville provides a publication platform for fully open access journals, which means that all articles are available on the Internet to all users immediately upon publication. However, the opinions and sentiments expressed by the authors of articles published in our journals do not necessarily indicate the endorsement or reflect the views of DigitalCommons@Cedarville, the Centennial Library, or Cedarville University and its employees. The authors are solely responsible for the content of their work. Please address questions to dc@cedarville.edu.

\section{Recommended Citation}

Lyons, Jonathan M. (2017) "From Silence to Golden: The Slow Integration of Instruments into Christian Worship," Musical Offerings: Vol. 8 : No. 1 , Article 2.

DOI: $10.15385 /$ jmo.2017.8.1.2

Available at: https://digitalcommons.cedarville.edu/musicalofferings/vol8/iss1/2 


\title{
From Silence to Golden: The Slow Integration of Instruments into Christian Worship
}

\section{Document Type}

Article

\begin{abstract}
The Christian church's stance on the use of instruments in sacred music shifted through influences of church leaders, composers, and secular culture. Synthesizing the writings of early church leaders and church historians reveals a clear progression. The early musical practices of the church were connected to the Jewish synagogues. As recorded in the Old Testament, Jewish worship included instruments as assigned by one's priestly tribe. Eventually, early church leaders rejected that inclusion and developed a rather robust argument against instruments in liturgical worship. The totalitarian stance on musical instruments in sacred worship began to loosen as the organ increased in use and popularity. Organs began to find a more regular place in churches by the twelfth century. While organ music set a precedent which will later allow for the entry of other instruments into the sanctuary, it took quite a while to do so. As the Protestant Reformation changed the face of the church, Martin Luther served a crucial role, not just as a theological leader, but also as the center of a new musical movement in the church. This Reformation began a series of reactions that eventually leads to the church's general acceptance of instruments in sacred worship.
\end{abstract}

\section{Keywords}

Music, church, church music, instrumental music, organ, liturgy, sacred worship

\section{Creative Commons License}

\section{(i) (i) $($ )}

This work is licensed under a Creative Commons Attribution-Noncommercial-No Derivative Works 4.0 License. 


\title{
From Silence to Golden: The Slow Integration of Instruments into Christian Worship
}

\author{
Jonathan M. Lyons \\ Cedarville University
}

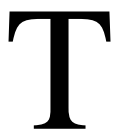
he music of the Christian church has undergone much change since its biblically recorded beginnings. One of the more controversial musical changes in the church, which occurred around the time of the Reformation, was centered on the propriety of intermixing musical instruments with the sacred liturgy. Throughout church history, the church's stance on the use of instruments in sacred music shifted through the influences of church leaders, secular culture, and innovative composers, as initially evidenced by the rising prominence of organ music in Christian worship. To speak of a shift necessitates a clear understanding of the starting point - an unaccompanied vocal liturgy, and of the end point-a liturgy where instruments serve for both accompaniment and liturgical functions. While the church's view on worship continues to shift even in the present day, this paper will focus primarily on the view of instrumental worship from the beginning of the Christian church through the death of Johann Sebastian Bach in 1750.

The early Christian musical tradition is connected to the Jewish tradition after the destruction of the temple in Jerusalem. According to author John Price, there seems to be no record of Jewish instrumental worship once the temple was destroyed in AD $70 .{ }^{1}$ Temple services had been highly inclusive of musical instruments. As recorded in the Old Testament, Jewish worship included instruments assigned by ancestral tribe and purpose. For example, shofars (horns) and trumpets were

${ }^{1}$ John Price, Old Light on New Worship: Musical Instruments and the Worship of God, a Theological, Historical and Psychological Study (Avinger, TX: Simpson Publishing, 2005), 65-67.

Musical Offerings, vol. 8, no. 1, pp. 13-22. ISSN 2330-8206 (print); ISSN 2167-3799 (online);

(C) 2017, Jonathan M. Lyons, licensed under CC BY-NC-ND 4.0 (http://creativecommons.org/licenses/by-nc-nd/4.0/) 
instruments reserved for the priestly tribe, while harps and lyres seemed to be designated as accompaniment for liturgical singing. ${ }^{2}$ Price connects the early musical practices of the church, however, to the Jewish synagogues. After the destruction of the temple, Jews worshiped exclusively in their local synagogues, which practiced unaccompanied vocal singing. Stylistically, local synagogues moved away from sacrificial and ceremonial traditions toward a simplistic and spiritual congregational feel. ${ }^{3}$

While there is evidence that the temple worship included instruments, the early church fathers developed a robust case, based on three primary arguments, against the inclusion of instruments in Christian worship. First, they argued that the Old Testament practices were no longer needed in the post-Jesus maturity of the church. Second, many felt that the references to instruments were best interpreted figuratively. ${ }^{4}$ Ignatius of Antioch was the first to put forth this particular view by allegorizing the harmony between Christ and the bishops as the well-tuned strings of a harp. ${ }^{5}$ Third, and most damning, musical instruments were considered to be closely aligned with immoral, pagan cult practices. ${ }^{6}$ These harsh attitudes were rooted in considerations of both doctrinal beliefs and practicality. When the early church faced persecution, the underground nature of its meetings mandated a secrecy and hushed tone not suited for instrumental practices in worship. ${ }^{7}$ Regardless of reasoning, the early church fathers were unanimous in their dismissal of instruments in worship. James McKinnon, a respected researcher on this topic, writes that "the antagonism which the Fathers of the early Church displayed toward instruments has two outstanding characteristics: vehemence and uniformity." "Second-century theologian Clement of Alexandria stated that the church employs "but one instrument, the peaceful Word alone, neither the old psaltery, nor the tuba, not drum or flute, loved of those

\footnotetext{
${ }^{2}$ Joseph Gelineau, Voices and Instruments in Christian Worship: Principles, Laws, Applications (Collegeville, MN: Liturgical Press, 1964), 149.

${ }^{3}$ Price, Old Light on New Worship, 65-67.

4 Ibid., 68.

${ }^{5}$ Ibid., 70.

${ }^{6}$ Ibid., 68.

${ }^{7}$ Edmund A. Bowles, "Were Musical Instruments Used in the Liturgical Service during the Middle Ages?” Galpin Society Journal 10 (1957): 47-48, doi:10.2307/841804.

${ }^{8}$ Price, Old Light on New Worship, 68.
} 
who arm for the fray." ${ }^{9}$ In AD 367, the Council of Laodicea formally forbade the use of musical instruments in the church. ${ }^{10}$ The ban on instruments, which began as a matter of conscience, evolved into concrete church policy by the end of the Middle Ages.

This totalitarian stance on the use of musical instruments in sacred worship, however, began to loosen as the organ increased in use and popularity. The organ has an impressive history, with documentations showing that some early forms of organs were available in Egypt, Rome, and Greece well before the birth of Christ. These rather primitive organs used a system of hydraulics to produce air pressure. ${ }^{11}$ John L. Girardeau writes that "when the organ was introduced into its worship it encountered strong opposition, and made its way but slowly to general acceptance." ${ }^{12}$ Such opposition had come from theologians such as Thomas Aquinas, who spoke frankly on the dangers of any instrumental use in the church, arguing that the Old Testament usage of instruments reflected the coarseness and carnality of the Israelites. ${ }^{13}$ Around AD 670, Pope Vitalianus introduced an organ into a Roman Catholic Church in Rome, resulting in what many consider to be the first recorded example of instruments in Christian worship. ${ }^{14}$ Another early example of the organ in worship comes from the eighth century. After King Pepin of France installed at his royal court the organ that he received as a gift from Byzantine Emperor Constantine V, his son, Charlemagne, had a replica of that organ built for the Cathedral of Aix-la-Chapelle. ${ }^{15}$ By the twelfth century, organs began to find a regular place in churches. Numerous sources verify an organ in the cathedral of Winchester that required seventy men to operate it and that produced a sound so great that a listener would "cover his ears with his hands." ${ }^{16}$ Organ music became a standard element of Roman Catholic liturgy by the end of the fifteenth

\footnotetext{
${ }^{9}$ Karl Weinmann, History of Church Music (Westport, CT: Greenwood Press, 1979), 182-183.

10 Price, Old Light on New Worship, 76.

${ }^{11}$ Erwin Esser Nemmers, Twenty Centuries of Catholic Church Music (Westport, CT: Greenwood Press, 1978), 149.

12 John L. Girardeau, Instrumental Music in the Public Worship of the Church

(Richmond, VA: Whittet \& Shepperson, 1888), 161.

${ }^{13}$ Ibid., 121-122.

${ }^{14}$ Price, Old Light on New Worship, 79.

${ }^{15}$ Weinmann, History of Church Music, 195.

${ }^{16}$ Herbert Gotsch and Edward W. Klammer, “The Music of Instruments,” in A Handbook of Church Music, ed. Carl Halter and Carl Schalk (St. Louis, MO: Concordia, 1978), 175.
} 
century, with one installed in nearly all prominent European churches. It was at this time that the religious and musical landscape of the church was about to be shaken to its core by the Reformation.

The first whisper of Reformation began with scholar and theologian John Wycliffe, who vocalized his condemnation of the Roman Catholic Church's practice of indulgences, among other theological concerns. Musically, Wycliffe felt that the high-art culture of the church was hindering the text from being heard and diminishing the presentation of the Gospel. After Wycliffe's death in 1384, the church managed to squash any potential uprising by quickly silencing other dissenters. ${ }^{17}$ Over 100 years later, on October 31, 1517, Martin Luther publicly posted ninety-five theses that outlined his theological grievances with the Roman Catholic Church and its doctrine. This led to his excommunication and the founding of the Protestant Church tradition, which would further divide between the followers of Luther, Calvin, and others.

Of the new Protestant denominations, the Lutheran Church had the richest musical culture. Luther himself is significant, not just as a theological leader, but also as the center of a new musical movement in the church. It has been said that he lived "with music ringing in his ears." 18 As a musician, Luther held music to be of upmost importance, so that "next to the Word of God, the noble art of music is the greatest treasure in this world. It controls our thoughts, minds, hearts, and spirits." 19 Unlike other Reformation offshoots, however, Luther's primary concerns were matters of doctrine and not of worship practices. He felt that anything not explicitly forbidden in scripture should be a matter of personal Christian liberty. ${ }^{20}$ His commitment to art grounded in biblical truth shaped the churches in both the new, reformed movement and in the Roman Catholic response-the CounterReformation.

Perhaps Luther's most direct musical influence can be seen in the German hymn. While there was a strong hymn tradition in Germany

\footnotetext{
${ }^{17}$ Andrew Wilson-Dickson, The Story of Christian Music (Minneapolis, MN: Fortress Press, 1996), 55-56.

${ }^{18}$ Carl F. Schalk, Luther on Music: Paradigms of Praise (St. Louis, MO:

Concordia, 1988), 9.

${ }^{19}$ Walter E. Buszin, Luther on Music (Saint Paul, MN: North Central Publishing, 1958), 5.

${ }^{20}$ Price, Old Light on Christian Worship, 87.
} 
prior to Luther, it had always been kept separate from the liturgy. From the Reformation onward, congregational hymns sung in the vernacular become the staple of Luther's churches, replacing the choir-sung, Latinbased liturgical mass. ${ }^{21}$ Eventually, organs and other instruments found a secure place in Lutheran Protestantism as accompaniment for those great hymns. Luther did, however, hold a very high view of Roman Catholic music and was not afraid to modify their preexisting music for acceptable use within the Protestant Church. Stated in the Formula missae of 1523, his policy was that "[i]n the meantime we shall try all things, what is good we shall retain." 22 As such, Luther had no hesitation to include instruments in the church service.

Many fellow reformers, however, held strong conviction against Luther's relaxed and inclusive views. The worship practices of Andreas Bodenstein of Carlstadt, Ulrich Zwingli, and John Calvin were strictly void of any instruments. Bodenstein (commonly known as Carlstadt) blamed the fall of the medieval church on the prevalence of music that demonstrated any level of significant technical skill or theatrical flair. He even unsuccessfully attempted to apply his views to Luther's church while Luther was away for a length of time. ${ }^{23}$ Carlstadt's writings greatly influenced Ulrich Zwingli, a leader in the Swiss Reformation. To further develop Carlstadt's historical and psychological objections, Zwingli was the first of the reformers to draw objections from the Word of God, which resulted in the regulative principle of worship. This principle states that only the scriptural commands prescribed for worship are acceptable practices and that anything outside of those commands is forbidden. ${ }^{24}$ This line of thought restricts instruments from the sacred service because the New Testament contains no command to use instruments. Zwingli succinctly stated, "Everything which is added to the true institutions of Christ is an abuse." ${ }^{25}$ His sect of the Reformation Era church, the Great Minister Church, stopped using the organ in 1524. In fact, Zwingli oversaw the removal of cathedral organs and vocal singing from all Zurich churches. ${ }^{26}$ Interestingly, there is some record that Zwingli was a talented instrumentalist, but, unlike Luther, he did not allow his personal passion for music to inform his views on worship. ${ }^{27}$

\footnotetext{
${ }^{21}$ Weinmann, History of Church Music, 59-60.

${ }^{22}$ Buszin, Luther on Music, 12.

${ }^{23}$ Price, Old Light on New Worship, 88.

${ }^{24}$ Ibid., 16.

25 Ibid., 90.

${ }^{26}$ Ibid., 91.

${ }^{27}$ Wilson-Dickson, The Story of Christian Music, 64.
} 
As perhaps the most "imposing figure of reform," John Calvin also kept a tight grip on musical worship practices. ${ }^{28}$ Like Zwingli, Calvin allowed for music in private as personal pleasure, providing that it did not contain frivolity or sensuality. ${ }^{29}$ He did, however, fervently reject instruments in Christian worship, based on his interpretation that the Old Testament use of instruments in temple services held no sway once Christ abolished the old covenant. Calvin completely countered Luther by stating Christian priority to be, "first, of the mode in which God is duly worshipped; and, secondly, of the source from which salvation is to be attained." ${ }^{30} \mathrm{He}$ argued, verging on the offensive, that musical instruments were "childish elements" that buried the "light of the Gospel." 31 The reformers' strict ban on instrumental church music was largely to avoid comparison with the music of the Roman Catholic Church-which allegedly could put one's soul at risk, and to avoid association with dance music-which could put one's morals at risk. ${ }^{32}$

Any discussion of post-Reformation church music would be incomplete without an examination of the resulting Roman Catholic CounterReformation. Perhaps the most concrete collection of CounterReformation views comes out of the Council of Trent, which met from 1545 to 1563, over twenty-five years after the beginning of the Protestant Reformation. The council's original purpose was to seek reconciliation with the reformers, but any chance of that had long passed by 1545 . Instead, the council prepared to recommend a number of adjustments to Roman Catholic doctrine and practice. ${ }^{33}$ The Roman Catholic Church felt an increasing pressure to offer clarity into its views on instruments in worship, as the reformers had. The council addressed only the organnoting that it could be permitted when played without that which was lascivum aut impurum (lascivious or impure) ${ }^{34}$ As the "symphonic wave of the baroque era" influenced the church, Pope Benedict XIV revisited the church's liturgical policies. In his Annus qui (1749), the pope took a balanced approach, both acknowledging the traditional exclusion of instruments and presenting the increasingly prevalent arguments for their inclusion. He concluded that "only the abuses should be reproved,"

\footnotetext{
${ }^{28}$ Wilson-Dickson, The Story of Christian Music, 65.

${ }^{29}$ Price, Old Light on New Worship, 99.

${ }^{30}$ Ibid., 93.

${ }^{31}$ Ibid., 96.

${ }^{32}$ Wilson-Dickson, The Story of Christian Music, 65.

${ }^{33}$ Ibid., 73-74.

${ }^{34}$ Gelineau, Voices and Instruments in Christian Worship, 153.
} 
which consisted of any "theatrical or profane musical genres." More specifically, he permitted only the organ, stringed instruments, and the flute, due to their ability to support the natural, human voice. This way, the more theatrical (and thus, banned) instruments could not hinder the worshiper's ability to be "penetrated by the meaning of the words." 35

In his study of the history of instruments in the church, French Jesuit priest (and composer) Joseph Gelineau outlined three basic principles for the use of instruments in the post-Reformation Roman Catholic Church. The first principle is that "vocal praise alone is essential to Christian worship. Instruments are only accessory." ${ }^{36}$ The second is that the playing of musical instruments "may in no way damage the holiness of Christian worship" and that it must "be free from all connection with idolatrous, profane, or worldly practices." ${ }^{37}$ The third principle, as championed by Pope Pius XII particularly, is that instrumentalists must acquire the "technical standard required in the playing of instruments if they are worthily to serve the sacred chant or action." ${ }^{38}$ It was Pius XII's opinion that the "power and splendor" of polyphonic church chants "were increased when the sounds of the organ and other musical instruments were joined with the voices of the singers." ${ }^{39}$ While Pius XII's papacy (1939-1958) lies outside the time range of this paper, his statements serve well to emphasize that the church's acceptance of instruments has continued to progress:

Among the musical instruments that have a place in church the organ rightly holds the principal position, since it is especially fitted for the sacred chants and sacred rites. It adds a wonderful splendor and a special magnificence to the ceremonies of the Church. It moves the souls of the faithful by the grandeur and sweetness of its tones. It gives minds an almost heavenly joy and it lifts them up powerfully to God and to higher things. Besides the organ, other instruments can be called upon to give great help in attaining the lofty purpose of sacred music, so long as they play nothing profane[,] nothing

\footnotetext{
${ }^{35}$ Gelineau, Voices and Instruments in Christian Worship, 154.

36 Ibid., 155.

${ }^{37}$ Ibid., 157.

${ }^{38}$ Ibid.

${ }^{39}$ Pius XII, “Musicae sacrae,” The Holy See, December 25, 1955, Section 15, http://w2.vatican.va/content/pius-xii/en/encyclicals/documents/hf_pxii_enc_25121955_musicae-sacrae.html.
} 
clamorous or strident[,] and nothing at variance with the sacred services or the dignity of the place. Among these the violin and other musical instruments that use the bow are outstanding because, when they are played by themselves or with other stringed instruments or with the organ, they express the joyous and sad sentiments of the soul with an indescribable power. ${ }^{40}$

As composing for instruments became more and more popular, instruments always seemed to find their way into the church. Without composers, the church lacks any music, instrumental or otherwise. One of the church's earliest recorded organists, rising to fame in the late fourteenth century, was Francesco Landini, though he was called "Cieco" because of his blindness. ${ }^{41}$ Some would consider the true start of notable organ compositions to begin with the uncle and nephew pair of Andrea (1556-1586) and Giovanni Gabrieli (1585-1612). The development of secular song and dance tunes in the late fifteenth century greatly influenced their organ style and led to a new understanding of chords and harmonic movement. ${ }^{42}$ (Of course, this influence only added fuel to the arsenal of any church leader who felt that instruments in and of themselves were too worldly for use in church services.) As the most prolific seventeenth-century organist, Girolamo Frescobaldi (15831644) was significant to the development of the fugue. His technical abilities and educational work influenced the next generations of organists. ${ }^{43}$ The next great master of organ, Dietrich Buxtehude (16371707) came from Germany. His expansive body of works demonstrated a maturation of organ composition: pedal independence, varied registers, and engaging effects.

Perhaps Buxtehude's greatest gift to the organ was his profound influence on Johann Sebastian Bach. ${ }^{44}$ Bach stands as a "Titan among the Masters of the organ, who incorporates in himself the musical power and feeling of a whole generation." ${ }^{45}$ His compositions from his posts at Weimar, Cöthen, and Leipzig solidified the organ's place in the church, and his settings of church liturgy also demonstrate adeptness in using

\footnotetext{
${ }^{40}$ Pius XII, “Musicae sacrae," Sections 58-59.

${ }^{41}$ Weinmann, History of Church Music, 197.

${ }^{42}$ Nemmers, Twenty Centuries of Catholic Church Music, 151.

${ }^{43}$ Weinmann, History of Church Music, 199.

${ }^{44}$ Nemmers, Twenty Centuries of Catholic Church Music, 153-154.

${ }^{45}$ Weinmann, History of Church Music, 202.
} 
other instruments for such purposes. ${ }^{46}$ Bach's compositions established the liturgical test for all organ music by remaining appropriate in length and by maintaining the spirit of the liturgical texts. These organ works became staples of the liturgy, particularly as processionals and recessionals. ${ }^{47}$

By the time of Bach's death, despite centuries of opposition from stalwart church fathers, a new generation of church leaders began to have open minds about new expressions of worship, namely through the playing of instruments. Any measurable progress typically results in disagreement, for though change is inevitable, it is rarely popular. Perhaps not even intentionally, figures such as Pope Vitalianus, Constantine V, Martin Luther, and Pope Benedict XIV each uniquely led the church toward musical inclusion. Many church leaders disagreed on the subject, and while some traditions returned to a culture of instrument exclusion, it seems that no institution can remain fully immune to the influence of its surrounding culture. As styles and tastes shifted, the church felt pressure to adjust accordingly while still maintaining some semblance of orthodoxy. The organ is particularly notable in church history for serving as a symbolic instrument of musical beauty and piety. Great composers like Gabrieli, Frescobaldi, Buxtehude, and finally Bach pushed the boundaries by inspiring all with sacred artistry and technical finesse. Through the influence of church leaders and composers who were greatly moved by cultural and religious beauty, the church gradually began to allow instruments in the sacred worship of God.

${ }^{46}$ Weinmann, History of Church Music, 201.

${ }^{47}$ Nemmers, Twenty Centuries of Catholic Church Music, 155. 


\section{Bibliography}

Apel, Willi. "Early History of the Organ,” Speculum 23, no. 2 (1948):

191-216. doi:10.2307/2852952.

Bowles, Edmund A. "Were Musical Instruments Used in the Liturgical Service during the Middle Ages?” Galpin Society Journal 10 (1957): 40-56. doi:10.2307/841804.

Buszin, Walter E. Luther on Music. Saint Paul, MN: North Central Publishing, 1958.

Gelineau, Joseph. Voices and Instruments in Christian Worship:

Principles, Laws, Applications. Translated by Clifford Howell.

Collegeville, MN: Liturgical Press, 1964.

Girardeau, John L. Instrumental Music in the Public Worship of the Church. Richmond, VA: Whittet \& Shepperson, 1888.

Gotsch, Herbert, and Edward W. Klammer. "The Music of

Instruments.” In A Handbook of Church Music, edited by Carl

Halter and Carl Schalk, 172-216. St. Louis, MO: Concordia, 1978.

Nemmers, Erwin Esser. Twenty Centuries of Catholic Church Music. Westport, CT: Greenwood Press, 1978.

Pius XII. “Musicae sacrae.” The Holy See. December 25, 1955.

http://w2.vatican.va/content/pius-xii/en/encyclicals/

documents/hf_p-xii_enc_25121955_musicae-sacrae.html.

Price, John. Old Light on New Worship: Musical Instruments and the Worship of God, a Theological, Historical, and Psychological Study. Avinger, TX: Simpson Publishing, 2005.

Schalk, Carl F. Luther on Music: Paradigms of Praise. St. Louis, MO: Concordia, 1988.

Weinmann, Karl. History of Church Music. Westport, CT: Greenwood Press, 1979.

Wilson-Dickson, Andrew. The Story of Christian Music. Minneapolis, MN: Fortress Press, 1996. 